Саратовский государственный аграрный университет имени Н.И. Вавилова. Россия.

410005, г. Саратов, ул. Соколовая, 355.

Тел.: (8452) 69-25-32.
Ключевые слова: ооцит; in vitro; наночастицы высокодисперсного кремнезема (нВДК); кумулюс; витрификация; Bos taurus.

\title{
EFFECTS OF HIGHLY DISPERSED SILICA NANOPARTICLES ON THE CRYORESISTANCE OF DEVITRIFIED BOS TAURUS CUMULUS-OOCYTE COMPLEXES
}

Kuzmina Tatiana Ivanovna, Doctor of Biological Sciences, Professor, Senior Researcher, All-Russian Research Institute of Genetics and Breeding of Farm Animals - branch of Federal State Budget Scientific Institution "Federal Scientific Center for Animal Husbandry - VIZH named after Academician L.K. Ernst". Russia.

Stanislavovich Tatyana Ivanovna, Candidate of Agricultural Sciences, Leading Re-searcher, All-Russian Research Institute of Genetics and Breeding of Farm Animals - branch of Federal State Budget Scientific Institution "Federal Scientific Center for Animal Husbandry - VIZH named after Academician L.K. Ernst". Russia.

Molchanov Aleksey Vyacheslavovich, Doctor of Agricultural Sciences, Professor, Head of the chair "Technology of Production and Processing of Livestock Product", Saratov State Agrarian University named after N.I. Vavilov. Russia.

Keywords: oocytes; in vitro; highly dispersed silica nanoparticles (HDSns); cumulus; vitrification; BosTaurus.

The creation of the donor oocytes cryobank in agricultural animals will make it possible to significantly improve the introduction of high-tech cellular reproductive and DNA technologies (in vitro production of embryos, cloning, transgenesis, genome editing) into the animal husbandry practice. Despite the considerable efforts of cryobiologists and embryotechnologists, the problem of Bos Taurus oocyte cryoresistance has not been adequate- ly solved. The search for effective cryoprotective agents (CPA) that preserve the integrity of cellular structures, their functional activity and the creation of a system for the cultivation of devitrified cells are the most important tasks of modern cryotechnologies. Highly dispersed silica nanoparticles (HDSns) are promising componentsfor optimizing CPA systems and media for cultivating somatic and germ cells of ovarian follicles, as well as pre-implantation embryos of animals. In the present study the nature of the effect of HDSns on the somatic (cumulus), germ cells (oocytes) of ovarian cow follicles and the fertility of the ova was identified. The positive effects of HDSns on the safety and functional state of cumulus cells after devitrification and cultivation of cumulus - oocyte complexes were shown. The level of devitrified oocytes that have cultured with $0.001 \%$ of HDSns and have reached the metaphase II, significantly exceeded the level of matured devitrified oocytes that have not treated with HDSns (60\% vs. $41 \%, P<0.001$ (2-test)).The yield of embryos at the blastocyst stage significantly increased when devitrified oocytes were cultured with HDSns (11\% (13/121) vs. 5\% (5/105), $P<0.05)$. In addition to the observed positive effects of the HDSns on the cumulus morphology and maturation of devitrified Bos Taurus oocytes, the data obtained contribute to a better understanding of the mechanisms of functioning of somatic and germ cells from ovarian follicles under ultralow temperatures.

\section{ВЛИЯНИЕ РАЗНЫХ УРОВНЕЙ МЕДИ НА ПЕРЕВАРИМОСТЬ ПИТАТЕЛЬНЫХ ВЕЩЕСТВ РАЦИОНА ЛАКТИРУЮЩИМИ ОВЦЕМАТКАМИ}

\author{
МАНДЖИЕВ Дмитрий Борисович, Национальный исследовательский Мордовский \\ государственный университет имени Н.П. Огарева
}

ГАЙИРБЕГОВ Джунайди Шарамазанович, Национальный исследовательский

Мордовский государственный университет имени Н.П. Огарева

В физиологических опытах изучено влияние различных уровней меди в рационах на переваримость питательных веществ лактирующими овцематками.

Введение. На физиологические процессы, протекающие в организме животных, оказывают влияние различные факторы: корма, их питательная ценность, наличие необходимых элементов питания, их соответствие рекомендуемым нормам [2, 6, 7]. Доказано, что жизне- деятельность микрофлоры рубца и метаболизм жвачных животных протекают нормально только тогда, когда с рационом поступают качественные сочные корма, а также определенное и эквивалентное количество минеральных веществ [4, 10-12]. 
При одностороннем увеличении или уменьшении количества какого-либо минерального элемента в рационе, в сравнении с его оптимальной нормой, могут происходить нарушения в балансе питательных и минеральных веществ, вследствие которых общее направление обменных процессов изменяется в нежелательную сторону $[1,3,5,8]$. В связи с этим цель данной работы - изучить влияние разных уровней меди, с учетом установленных нами ранее норм, на переваримость питательных веществ рациона лактирующими овцематками.

Методика исследований. Научно-хозяйственный опыт и на его фоне физиологические опыты на овцематках калмыцкой курдючной породы в начале и конце лактации проводили в условиях К $(\Phi) \mathrm{X}$ «Будда» Республики Калмыкии. Научно-хозяйственный опыт проводили согласно приведенной схеме (табл. 1).

Для опыта по принципу аналогов были отобраны 30 голов овцематок после ягнения, с ягнятами одинцами, живой массой 58-60 кг. Животных распределили на три группы по 10 голов в каждой. На фоне данного опыта в начале и конце лактации животных были проведены балансовые опыты. Для этого отбирали по 3 головы из каждой группы. Во время проведения балансовых опытов все овцематки находились в одинаковых условиях кормления и содержания и отличались лишь количеством содержа- ния меди в рационах. Животные 1-й опытной группы получали основной рацион, в котором медь содержалась в соответствии с нормами, рекомендуемыми РАСХН [9], в количестве 21 мг на 1 голову в сутки в начале лактации и 17,5 мг в ее конце, то есть на $30 \%$ меньше нормы, установленной нами ранее.

Овцематки 2-й группы получали медь согласно установленной нормы в начале лактации в количестве 30 мг, а в конце 25 мг на 1 голову в сутки, за счет основного рациона и добавки к нему 38 мг сернокислой меди в начале лактации и 32 мг в конце лактации. Овцематки 3-й группы получали медь сверх нормы на 30 \%, за счет добавки 76 мг сернокислой меди в начале и 64 мг в конце лактации. Скармливали сернокислую медь ежедневно в смеси с концентратами и с другими минеральными добавками.

При выполнении химических анализов образцов балансового опыта пользовались общепринятыми методиками.

Результаты исследований. В результате проведенных нами исследований было установлено, что изменение уровня меди в рационах лактирующих овцематок оказывает заметное влияние на переваримость питательных веществ (табл. 2).

Так, с течением лактации овцематок происходит снижение переваримости сухого и органического вещества, сырого протеина, жира и безазотистых экстра-

Таблица 1

Схема научно-хозяйственного опыта

\begin{tabular}{|c|c|c|c|}
\hline Группа & Количество голов & Рацион & Уровень меди в рационе, мг \\
\hline \multicolumn{4}{|c|}{ В начале лактации } \\
\hline $1-я$ & 10 & Основной рацион (OP) & $21(-30 \%)$ \\
\hline $2-я$ & 10 & ОР + 38 мг сернокислой меди & 30 (норма) \\
\hline 3-я & 10 & ОР + 76 мг сернокислой меди & $39(+30 \%)$ \\
\hline \multicolumn{4}{|c|}{ В конце лактации } \\
\hline $1-я$ & 10 & Основной рацион (ОР) & $17,5(-30 \%)$ \\
\hline $2-я$ & 10 & OP + 32 мг сернокислой меди & 25 (норма) \\
\hline 3-я & 10 & ОР + 64 мг сернокислой меди & $32,5(+30 \%)$ \\
\hline
\end{tabular}

Таблица 2

Влияние уровня меди на коэффициенты переваримости питательных веществ

\begin{tabular}{|l|c|c|c|c|c|c|}
\hline Группа & $\begin{array}{c}\text { Сухое } \\
\text { вещество }\end{array}$ & $\begin{array}{c}\text { Органическое } \\
\text { вещество }\end{array}$ & $\begin{array}{c}\text { Сырой } \\
\text { протеин }\end{array}$ & $\begin{array}{c}\text { Сырой } \\
\text { жир }\end{array}$ & $\begin{array}{c}\text { Сырая } \\
\text { клетчатка }\end{array}$ & БЭВ \\
\hline Первая половина лактации \\
\hline 1 -я & $67,15 \pm 0,16$ & $69,60 \pm 0,30$ & $64,17 \pm 0,50$ & $61,01 \pm 0,44$ & $52,70 \pm 0,32$ & $81,13 \pm 0,38$ \\
2 -я & $71,80 \pm 0,22$ & $74,15 \pm 0,42$ & $67,53 \pm 0,70$ & $64,26 \pm 0,35$ & $56,05 \pm 0,20$ & $87,86 \pm 2,02$ \\
3 -я & $68,20 \pm 0,35$ & $70,50 \pm 0,28$ & $65,69 \pm 0,37$ & $62,18 \pm 0,34$ & $53,79 \pm 0,32$ & $83,90 \pm 2,49$ \\
\hline \multicolumn{7}{|c|}{ Вторая половина лактации } \\
\hline 1 -я & $65,06 \pm 0,37$ & $68,40 \pm 0,24$ & $61,76 \pm 0,43$ & $60,24 \pm 0,42$ & $53,66 \pm 0,32$ & $81,15 \pm 0,20$ \\
2 -я & $68,60 \pm 0,40$ & $72,00 \pm 0,50$ & $64,34 \pm 0,33$ & $63,55 \pm 0,39$ & $57,90 \pm 0,45$ & $84,54 \pm 0,80$ \\
3 -я & $66,12 \pm 0,45$ & $69,15 \pm 0,47$ & $62,49 \pm 0,34$ & $61,70 \pm 0,34$ & $54,20 \pm 0,40$ & $81,88 \pm 0,57$ \\
\hline
\end{tabular}


ктивных веществ и, наоборот, переваримость клетчатки с лактацией животных повышается. Переваримость сухого вещества за изучаемый период снизилась на 2,1$3,2 \% \quad(P<0,01)$, органического вещества - на $1,2-2,1 \%(P<0,05)$, протеина - на 2,4$3,2 \%(P<0,05)$, жира - на 0,48-0,77\% $(P>0,05)$, БЭВ - на $3,3-2,0 \%(P>0,05)$. Переваримость клетчатки в отличие от этих веществ повысилась на 0,4-1,8 \% $(P<0,05)$.

Высокий обмен веществ у овец в начале лактации, по-видимому, обусловлен большей потребностью организма в питательных веществах, необходимых для продуцирования молока, а в конце лактации из-за сокращения секреции молока обмен веществ снижается.

Оптимизация уровня меди в рационах лактирующих овцематок мясосального направления продуктивности 2-й группы способствовала повышению переваримости всех питательных веществ за весь период лактации. Пониженное на 30 \% количество меди в рационах маток 1-й группы привело к ухудшению переваримости сухого вещества в начале лактации на 4,65 \% $(P<0,001)$, в конце - на $3,54 \%(P<0,01)$, органического вещества - на 4,55 и 3,60 \% $(P<0,01)$, сырого протеина - на 3,36 и 2,58 \% $(P<0,05)$, сырого жира - на 3,25 и 3,31 \% $(P<0,05)$, клетчатки - на 3,35 и 4,24\% $(P<0,01)$, безазотистых экстрактивных веществ - на 6,73 и 3,39\% $(P<0,05)$ по сравнению со 2-й группой.

При избытке этого элемента появляется тенденция ухудшения переваримости всех питательных веществ, особенно протеина, клетчатки и БЭВ. Следует отметить, что животные, получавшие избыточное количество меди, переваривали питательные вещества лучше по сравнению с животными, в рационе которых былегонедостаток. Например, подсосныеовцематки 3-й группы по сравнению с 1-й усваивали лучше сухое вещество на 1,05 \% ( $P>0,05)$, органическое вещество - на 0,90-0,75 \% ( $P>0,05)$, сырой протеин на 1,52-0,73 \% (P>0,05), сырой жир - на 1,17-1,46 \% (P>0,05), сырую клетчатку - на 1,10-0,54\% $(P>0,05)$, БЭВ - на 2,77$0,73 \%(P>0,05)$.

Таким образом, установленная нами норма меди в рационах подсосных овцематок 2-й группы способствует лучшей переваримости питательных веществ по сравнению с аналогами 1-й и 3-й групп.

Заключение. Сравнительное изучение переваримости питательных веществ лактирующими овцематками при использовании рацио- нов с различным уровнем меди свидетельствует об эффективности установленных норм этого элемента. Оптимизация питания по меди обеспечивает лучшую переваримость питательных веществ рационов, что следует рассматривать как одно из средств воздействия на молочную и шерстную продуктивность и состояние здоровья овцематок.

\section{СПИСОК ЛИТЕРАТУРЫ}

1. Андреев А.И., Лапшин С.А., Тясин А.В. Потребность ремонтных телок в меди // Зоотехния. 1996. - № 10. - С. 15-17.

2. Влияние аспарагинатов микроэлементов на метаболизм молочных коров / А.П. Коробов [и др.] // Молочное и мясное скотоводство. 2015. - № 4. - С. 31-34.

3. Гайирбегов Д.Ш., Кокорев В.А. Оптимизация молибденового питания овец в онтогенезе. - Caранск, 2002. - 124 с.

4. Использование гидропонного зеленого корма для оптимизации зимних рационов крупного рогатого скота / А.А. Васильев [и др.] // Аграрный научный журнал. - 2016. - № 3. C. $13-16$.

5. Кальницкий Б.Д. Минеральные вещества в кормлении животных. - Л.: Агропромиздат, 1985. 207 c.

6. Коробов А.П., Москаленко С.П. Морфологические и биохимические показатели кров при использовании в рационах ремонтных телок сенажа в упаковке / / Аграрный научный журнал. - 2005. № 4. - C. 12-14.

7. Кузнецов М.Ю., Васильев А.А., Сивохина Л.А. Производство и использование гидропонных зеленых кормов в молочном козоводстве // Перспективные направления исследований в изменяющихся климатических условиях (посвящается 140-летию А.Г. Дояренко): сб. докл. Междунар. науч.-практ. конф. молодых ученых и специалистов. - Саратов, 2014. - С. 593-597.

8. Москаленко С.П., Кузнецов М.Ю. Рубцовое пищеварение коров при кормлении сенажом, заготовленным в пленочной упаковке // Зоотехния. - 2003. - № 7. - С. 11-12.

9. Нормы и рационы кормления сельскохозяйственных животных / А.П. Калашников [и др.]. - М.: Агропромиздат, 2003. -С. 212-214.

10. Оптимизация полноценного кормления мясных пород крупного рогатого скота на основе использования местных кормовых ресурсов для юго-восточной микрозоны Саратовской области / С.П. Москаленко [и др.] // Аграрная наука в XXI веке: проблемы и перспективы: материалы VIII Всерос. науч.-практ. конф.; под ред. И.Л. Воротникова. - Саратов, 2014. - С. 250-253.

11. Рекомендации по использованию гидропонических зеленых кормов в рационах крупного рогатого скота / А.А. Васильев [и др.]. - Саратов, 2013. - 35 c.

12. Manieson V.E., Kachepa U.E., Vasiliev A.A. Use of humic acids in cattle production // Аграрный научный журнал. - 2018. - № 5. - С. 35-36. 
Манджиев Дмитрий Борисович, канд. с.-х. наук, докторант кафедры зоотехнии им. профессора С.А. Лапшина, Национальный исследовательский Мордовский государственный университет имени Н.П. Огарева. Россия.

Гайирбегов Джунайди Шарамазанович, д-р c.- х. наук, проф. кафедры зоотехнии им. про- фессора С.А. Лапшина, Национальный исследовательский Мордовский государственный университет имени Н.П. Огарева. Россия.

430904, г. Саранск, р.п. Ялга, ул. Российская, 31. Тел.: (8342) 25-41-65; e-mail: kafedra_zoo@mail.ru.

Ключевые слова: лактирующие овцематки; переваримость; питательные вещества.

\title{
NFLUENCE OF DIFFERENT LEVELS OF COPPER ON PERCEPTION OF NUTRITIVE FEEDS OF THE RATION BY LACTATING EWES
}

Mandzhiev Dmitry Borisovich, Candidate of Agricultural Sciences, Doctoral Candidate of the chair "Zootechnics named after Professor S.A. Lapshin", National Research Mordovia State University named after N.P. Ogarev. Russia.

Gayirbegov Dzhunaidi Sharamazanovish, Doctor of Agricultural Sciences, Professor of the chair "Zootechnics named after Professor S.A. Lapshin", National Research
Mordovia State University named after N.P. Ogarev. Russia.

Keywords: lactating; ewes; digestibility; nutrients.

The effect of different levels of copper in rations on the digestibility of nutrients in the diet by lactating ewes has been studied in physiological experiments.

\section{СОВРЕМЕННЫЕ МЕТОДЫ ЛЕЧЕНИЯ БРОНХОПНЕВМОНИИ ТЕЛЯТ В УСЛОВИЯХ ЖИВОТНОВОДЧЕСКИХ КОМПЛЕКСОВ}

\author{
ПОЛОЗЮк Ольга Николаевна, Донской государственный аграрный университет \\ ЛАПИНА Татьяна Ивановна, Донской государственный аграрный университет
}

\begin{abstract}
Установлено, что причиной возникновения бронхопневмонии молодняка явилосъ несоблюдение зоогигиенических норм содержания после отбивки от матерей. При использовании схемы лечения, в состав которой входили энрофлокс, сыворотка против пневмоэнтеритов, 9-валентная сыворотка, дексаметазон и иммунофан, выздоровление опытных животных наступало на 4 дня раньше контрольных. Они имели лучшие морфологические показатели крови: количество эритроцитов и гемоглобина на 14-й день после выздоровления было на 15,3 и 15,2 \% выше, чем у аналогов контрольной группы. При исследовании лейкограммы отмечали, что у заболевших телят до начала лечения наблюдался нейтрофильный лейкоцитоз со сдвигом ядра влево, моноцитопения, указывающая на снижение резистентности организма. После курса лечения у всех животных показатели нейтрофильной группы стабилизировались, а количество моноцитов увеличилось на 30 \% по сравнению с контролем. Связано это с применением иммуностимулятора иммунофана.
\end{abstract}

Введение. Интенсивному развитию мясомолочных комплексов промышленного типа отводится большая роль в обеспечении страны продовольствием. Наряду с совершенствованием производственно-технологической оснащенности необходимо комплектовать их здоровым поголовьем, что обязывает ветеринарных специалистов повышать уровень организации ветеринарного обслуживания, своевременно проводить профилактические, ветеринарно-санитарные мероприятия с целью предупреждения заноса заразных и возникновения незаразных болезней $[1,2]$.

Иногда решение этих вопросов ослож- няется нарушением зоогигиенических требований и несбалансированностью рациона кормления, что ведет к нарушению обмена веществ, снижению резистентности организма животных, рождению ослабленного молодняка и возникновению различных болезней [4].

В крупных хозяйствах с большой концентрацией поголовья молодняка массовая заболеваемость животных бронхопневмонией регистрируется часто на фоне вспышки бактериальных, вирусных, микоплазменных респираторных инфекций. Поэтому необходимо регулярно проводить специальные лабораторно-диагностичес- 